\title{
Banking Law and Economic Development in Nigeria: Contributions and Constraints of the Banks and Other Financial Institutions Act
}

\author{
Matthew Enya Nwocha \\ Faculty of Law, Ebonyi State University, Abakaliki, Nigeria \\ Email: nwochaenyaeni@gmail.com
}

How to cite this paper: Nwocha, M. E. (2017). Banking Law and Economic Development in Nigeria: Contributions and Constraints of the Banks and Other Financial Institutions Act. Beijing Law Review, 8, 451-464.

https://doi.org/10.4236/blr.2017.84025

Received: October 4, 2017

Accepted: December 9, 2017

Published: December 12, 2017

Copyright $\odot 2017$ by author and Scientific Research Publishing Inc. This work is licensed under the Creative Commons Attribution International License (CC BY 4.0).

http://creativecommons.org/licenses/by/4.0/

\begin{abstract}
This paper titled "Banking Law and Economic Development in Nigeria: Contributions and Constraints of the Banks and Other Financial Institutions Act" came against the background of the current instability and uncertainty in the Nigerian banking sector and the need to strengthen the regulatory regime for optimal performance of the sector. The Banks and Other Financial Institutions Act is the principal legislation regulating banking in Nigeria and has a general application to all banks. This paper has therefore examined the strengths and weaknesses of this Act and measured its contributions to economic development in the country as well as its inherent constraints. The paper has found, among other things that the Act has contributed immensely to economic growth in the country through a multi-dimensional sectoral approach. However, a number of defects in the Act still need to be rectified. The paper has recommended the easing of over-regulation by striking out certain self-contradictory and ambiguous provisions that are open to abuse as well as placement of much more reliance on the courts for enforcement rather than the unguarded discretion allowed the Central Bank of Nigeria, among other things.
\end{abstract}

\section{Keywords}

Banking Business, Regular Banks, Specialized Banks, Over-Regulation, Creditors

\section{Introduction}

There exist in Nigeria well above two dozen legislations regulating the operation of banks and other financial institutions and organizations, including issues 
relating to loans, guarantees, currency matters and development financing. ${ }^{1}$ There are often clear significations of over-regulation in the banking sector which might be a product of the anxiety of managers of the economy to apply all possible and necessary legislative and executive measures to stake up and sustain a buoyant economy by plugging all perceived loopholes and weaknesses. This, again, is a recognition of the central and fundamental role that banks play in economic development. As experience has shown worldwide, the failure of the banking sector always invariably leads to the collapse of the economy. There is illustration of this in USA, Nigeria and Greece where recession in those countries in the past decade emanated from bank failures. By the Constitution of the Federal Republic of Nigeria, 1999, banking and banking related matters are under the exclusive authority of the federal government. In fact, Part 1 of the Second Schedule to the constitution gives the federal government the exclusive authority to make laws and implement the laws it has made with regard to matters connected with bankruptcy and insolvency; banks, banking, bills of exchange and promissory notes; borrowing of monies within or outside Nigeria for the purposes of the Federation or of any State; control of capital issues, currency, coinage and legal tender; and exchange control ${ }^{2}$. Accordingly, the States and local governments only have to comply with the laws made by the National Assembly on behalf of the federal government in this regard, including the polices and subsidiary regulations made by the institutions and agencies of the federal government on the above subject-matters. More than this, only federal courts, to a substantial degree, have the jurisdiction to entertain matters connected with banking and currency issues.

This paper is not intended to study all of the laws connected with banking, currency and development financing in Nigeria, for such an exercise would be too unwieldy for a single paper. On the other hand, the paper aims at appraising the principal banking legislation in the country, namely, the Banks and Other Financial Institutions Act to determine its relevance and contributions to the development of the Nigerian economy. The paper is also intended to ascertain

\footnotetext{
${ }^{1}$ Among them are the Central Bank of Nigeria Act, 2007; the Banks and Other Financial Institutions Act, 1991; Banking (Freezing of Account) Act; Banks (Motor Vehicle Loans) Miscellaneous Provisions Act; Central Bank (Currency Conversion) Act; Community Banks of Nigeria Act; Counterfeit Currency (Special Provision) Act; Currency Conversion (Freezing Orders) Act; Currency Offences Act; Decimal Currency Act; Dishonoured Cheques (Offences) Act; Failed Banks (Recovery of Debts) and Financial Malpractices in Banks Act; Federal Mortgage Bank of Nigeria Act; Finance (Control and Management) Act; Foreign Currency (Domiciliary Accounts) Act; Foreign Exchange (Monitoring and Miscellaneous) Provisions Act; General Loan and Stock Act; Government Promissory Note Act; Internal Loans Act; Internal Loans (Rehabilitation, Reconstruction and Development) Act; International Financial Organizations Act; Loan (Internal Borrowing) Act; Loan (State Development) Act; Loan Act; Local Loans (Registered Stock and Securities) Act; Ministry of Finance Incorporated Act; Money Laundering Act; Mortgage Institutions Act; Nigeria Export-Import Bank Act; Peoples Bank of Nigeria Act; Railway Loan (International Bank) Act; Revolving Loans Fund for Industry Act; Saving Bonds and Certificate Act; Treasury Bills Act; Treasury Certificates Act; and Urban Development Bank of Nigeria Act.

${ }^{2}$ See items 5, 6, 7, 12, 15 and 24 respectively of Part 1 of the Second Schedule to the Constitution of the Federal Republic of Nigeria, 1999.
} 
the constraints confronting the Act and finding solutions to those constraints to enable the Act contribute optimally to the development of the banking sector in the country, in particular, and the growth of the economy in general.

\section{Conceptual Framework}

The Black's Law Dictionary defines bank as a financial establishment for the deposit, loan, exchange, or issue of money and for the transmission of funds (Garner, 2009). In Federal Mortgage Bank of Nigeria vs. Nigeria Deposit Insurance Corporation, ${ }^{3}$ the Supreme Court of Nigeria defined a bank simply as an organization or place that provides financial services. It would appear that this is the operative definition of a bank for Nigerian Courts considering the pervasive influence of judicial precedent and stare decisis in a country where the Supreme Court is the apex court and final arbiter in all matters relating to judicial decisions. Incidentally, neither the country's constitution nor her Interpretation Act volunteered any assistance in this regard as none made any definition. Notwithstanding, section 61 of the Banks and Other Financial Institutions Act states that bank_means a bank licenced under the Act, and proceeds to define banking business as the business of receiving deposits on current account, savings account or other similar account; paying or collecting cheques drawn by or paid in by customers; provision of finance; or such other business as the governor of the Central Bank may by order published in the gazette designate as banking business. The Central Bank of Nigeria (CBN) Act adopts the definition for a bank contained in the Banks and other Financial Institutions Act (Adebayo, 1999). Our working definition, therefore, is that a bank is an institution, whether public or private, that provides financial services and engages in other activities in compliance with section 61 of the Banks and Other Financial Institutions Act.

\section{Rationale for Banking Regulation}

Banking law is the law that regulates the banking sector of the economy, and occupies a strategic position in the economic system of any nation. It is the purveyor and enforcer of government's fiscal and monetary policies (Afolabi, 1999). ${ }^{4}$ It is a firm and reliable weapon in the hands of government for the control and regulation of economic activities in the country. Governments worldwide have good reasons for regulating the banking sector. First, there is the need to secure the safety of depositor's funds. Some of the funds deposited in the banks are the life savings of people. In the era of rampant bank failures in the country, people lost their life and other savings without a remedy. This shattered the confidence that people had in banking thereby ushering in a general reluctance to deposit money in the banks leading to palpable decline in national savings and capital formation. The alternative to this was that people tended to retain

\footnotetext{
${ }^{3}$ (1999) 2 NWLR (Pt. 59) 333 at 361. This definition has been adopted in subsequent decisions of the Supreme Court such as in Associated Discount House Ltd vs. Almagamated Trustee Ltd (2009) 26 NSCQR 1240 at 1244 ratio 1 and 10.

${ }^{4}$ This is also illustrated section 60 of the CBN Act, 2007.
} 
their funds and such substantial capital formation outside the banking system could not be effectively mobilized for economic growth. As such, it became imperative to introduce measures to safeguard such savings. This explains the introduction by the Nigerian government of the Nigerian Deposit Insurance Corporation Act, the Failed Banks Act, and other related regulations. Second, there is the need to control bank charges and interest rates. If banks are not reigned in with regard to interest rates and other charges, they would only resort to profit maximization which would in turn affect businesses and other essential capital projects negatively. To avert this dire consequence, the Nigerian National Assembly has enacted the Finance (Control and Management) Act, General Loan and Stock Act, Internal Loans Act, and other related legislations. Third, there is also the need to prevent under-capitalized institutions from operating in the financial sector to avoid speculative financial bubbles and also curb excessive money supply in the economy that can lead to inflation. Four, without regulation most banks would probably concentrate their branches in urban cities where wealthier and higher number of customers would invariably occasion higher profit margins. This may be good for the banks but not for the economy as even distribution of bank branches across the country, including urban and rural areas, would be. Five, because banks deal with public money there is need for government to introduce measures to avoid abuse and diversion of the funds generated from the public. Accordingly, banking legislations prevent unsecured loans and unethical grants, loans and allowances to bank employees and directors. This helps to limit the financial risks of the banks. Six, regulating the banking system in a developing economy enables funds to be chanelled evenly to critical sectors of the economy, such as agriculture, education, energy and power, as well as manufacturing, industry and infrastructure projects, without which banks would have been inclined to concentrate their resources on high profit sectors such as trade, commence and import financing to the detriment of the even development of the economy. Seven, through the instrumentality of law, government is able to enforce a healthy competition among banks and neutralize any form of monopoly by, for instance, stipulating guidelines for activities such as mergers and take-overs. Eight, again banking laws are designed to compel banks to retain a certain percentage of their paid up capital and profits as statutory reserves which would come in aid during periods of under-capitalization, less liquidity, or expansion (Okaro, 2013; Afifia-Oru, 2009; Onuoha, 2013).

In general, these and other objectives are what the Banks and Other Financial Institutions Act is intended to achieve. We shall shortly turn our attention to this Act for critical analysis. ${ }^{5}$ Before then, it needs be pointed out that, as Afolabi has observed, there are a number of dangers inherent in the over-regulation of the banking system including regulatory inconsistency, instability in government policies, high cost of enforcing the regulatory regime, too many supervisory institutions, compelling banks to undertake high risk ventures that can lead

${ }^{5}$ The Act is enforced principally by the Central Bank of Nigeria, itself established by the Central Bank of Nigeria Act. 
to insolvency and eventual liquidation, lack of adequate consultation with banks on policy matters and thwarting of their preferred choices of operation, aside of a myriad number of other constraints (Afolabi, 1998; Okaro, 2013). Any banking law therefore needs to be wary of these dangers if it must accomplish its objectives.

\section{The Banks and Other Financial Institutions (BOFI) Act and Economic Development in Nigeria}

The Banks and Other Financial Institutions Act, otherwise referred to as the BOFI Act, was enacted into law in 1991 as a decree of the then Federal Military Government. The Act at inception was a fundamentally flawed legislation owing to a number of factors. The military junta that promulgated the decree had limited expertise at their disposal coupled with lack of adequate consultation with stakeholders which is always the case with the military that was given to making decisions by fiat. For these and other reasons, the decree could not cope with the increasing volume of banking services and their attendant volatility that had started from the 1980s and intensified through the 1990s. It is no wonder then that after a couple of years of fumbling through the banking sector without any meaningful economic progress, the decree was amended in 1997 and again in 1998. ${ }^{6}$ Yet the problems in the banking sector persisted. In 1999, following the ushering in of a civilian administration, the decree was re-enacted as an Act of the National Assembly with more amendments introduced. The Act was again amended in 2002 by the Banks and Other Financial Institutions (Amendment) Act, 2002. By this, the Banks and Other Financial Institutions Act incorporates the principal Act of 1991 and the 1998, 1999 and 2002 amendments. In spite of these amendments, the BOFI Act has not succeeded in resolving all the problems in the Nigerian banking sector.

Section 1 of the BOFI Act highlights the crucial role that the Central Bank of Nigeria has to play in enforcing the Act. By Section 2, no person shall carry on any banking business in Nigeria if it is not a company duly incorporated under the Companies and Allied Matters Act and holds a valid banking licence granted by the Central Bank of Nigeria under the BOFI Act. And by Section 3, any person desiring to undertake banking business in Nigeria shall apply in writing to the governor of the Central Bank for the grant of a licence and shall accompany the application with a feasibility report of the proposed bank; a draft copy of the memorandum and articles of association, a list of the shareholders, directors and principal officers of the proposed bank and their particulars; the prescribed application fee; and such other information, documents and reports as the Central Bank may specify from time to time. However, to avoid arbitrariness with regard to the requirements for issuance of a licence, Section 5(4) of the BOFI Act mandates that where the governor of the Central Bank intends to vary, revoke or impose fresh or additional conditions on a licence, he shall first give notice of his 
intention to the bank concerned and allow the bank to make representations to him in that behalf. However, the BOFI Act does not say what happens to the representations that the bank may make. Indeed whether the Central Bank shall accept and be guided by the representations or jettison it at will. This is striking especially against the background that the bank in question has exerted itself to obtain the licence only for the Central Bank to revoke or vary the conditions and proceed to impose penal sanctions on the bank for failure to comply with such additional and usually unexpected conditions. This is an illustration of over-regulation which can result in uncertainty in banking business.

Furthermore, Section 6(1) of the BOFI Act provides that no bank may open or close any branch office anywhere within or outside Nigeria except with the prior consent in writing of the Central Bank. This requirement of the law is good as it makes for even distribution of bank branches across the country particularly between Nigeria's few congested urban cities and its vast rural communities. A concentration of banking services in urban centres will increase the profit margin of banks because of the advantages of cheaper power utility due to access to national electricity grid; security and access to modern facilities and the Central Bank branches; and high volume of wealthy companies and other customers. Therefore, naturally, banks would want to concentrate their branches in urban areas. But such concentration of banks in a few cities is not good for a comprehensive and long term economic growth. Capital assets and savings in rural communities also need to be sucked into the national economy, aside of the even spread of beneficial banking services that can stimulate economic activities in the rural areas and, in the end, reduce rural migration to urban cities particularly with Nigeria's vast agricultural potentials remaining yet untapped in the rural areas. Therefore, Section 6(2) that imposes penal sanction for arbitrary closure and opening of bank branches is a welcome step in the right direction and makes for even development of the economy.

Section 8(1) prohibits any foreign bank from operating a branch office or representative office in Nigeria without a prior approval of the Central Bank which, under Section 8(2), has the power to grant a licence, subject to conditions imposed by it, to any bank registered in Nigeria or a foreign bank to undertake off-shore banking business from Nigeria. Even though the BOFI Act is not explicit on the nature of approval that may be granted to a foreign bank, we can make a reasonable supposition that is expressed in terms of the conditions relating to the license that the Central Bank can grant. This supposition is fortified by Section 8(3) that forbids any person, whether a citizen of Nigeria or a non-Nigeria from carrying on any banking business in Nigeria without a valid banking licence issued by the Central Bank. Again, Section 9(1) of the BOFI Act authorizes the Central Bank to determine or prescribe, from time to time, the minimum paid-up share capital requirement of each category of banks licened under the Act. This is in tune with Section 13(1) of the Act stipulating that a bank shall maintain at all times capital funds unimpaired by losses in such ratio to all or 
any assets or to all or any liabilities or to both such assets and liabilities of the bank and all its offices in and outside Nigeria as may be specified by the Central Bank. Again, Section 15(1) insists that every bank shall maintain with the Central Bank cash reserves and special deposits and hold specified liquid assets or stabilization securities, as the case may be, not less in amount than as may from time to time be prescribed by the Central Bank. This is again complemented by Section 16(1) that stipulates that every bank shall maintain a reserve fund out of its net profit constituted of thirty percent of such profit where the amount of the reserve fund is less than the paid-up capital, and fifteen percent where the amount of the reserve fund is equal or in excess of the paid-up share capital. Section 9(2) stipulates that failure by any bank to comply with any such determination or prescription shall be a valid ground for the Central Bank to revoke any licence issued to such erring bank. Section 13(2) empowers the Central Bank to prohibit any erring bank from advertising for or accepting new deposits, granting credit and making investment; or paying cash dividend to shareholders. Section 14(1) provides that failure by a bank to comply with the provisions of Section 13 may constitute a ground for the revocation of the operating licence of any bank. ${ }^{7}$ In addition, Sections $8(4), 15(5)$ and 16(2) of the BOFI Act impose fines of five hundred thousand naira (N500,000.00) for each offence and for each day it occurs on any bank that violates the requirements on adequate capitalization under Sections 8, 9, 13, 15 and 16 of the Act. It is our considered view that even with the current weak state of the naira which is exchanging at above three hundred naira to one US dollar at the foreign exchange market, this fine regime is strong enough to deter any recalcitrant bank. All of these go to the question of adequate capitalization of banks. Adequate statutory reserves for banks are a panacea for the risk of bank failure. And the BOFI Act by insisting on these measures has taken bold and effective steps to guarantee stability in the banking sector with the attendant positive effects on the economy.

There are, however, other grounds for the revocation of the operating licence of a bank. Section 12(1) of the BOFI Act empowers the governor of the Central Bank to, with the approval of the Board of Directors and by notice published in the gazette, revoke any licence granted to a bank if such bank ceases to carry on in Nigeria the type of banking business for which the licence was issued for any continuous period of six months or any period aggregating six months during a continuous period of twelve months; goes into liquidation or is wound up or otherwise dissolved; fails to fulfill or comply with any condition subject to which the licence was granted; has insufficient asset to meet its liabilities; or fails to comply with any obligation imposed upon it by the Central Bank in exercise of the powers conferred on it by the BOFI Act. This power of revocation of licence

\footnotetext{
${ }^{7}$ This is supported by section 15(4) empowering the Central Bank to withdraw any privileges or facilities normally accorded to banks from any bank that violates the requirements of minimum holding cash reserves, specified liquid assets, special deposits and stabilization securities. Note again that banks under section 16(3) of the BOFI Act are permitted to create additional reserve funds in excess of the statutory requirements.
} 
is the ultimate weapon in the armoury of the Central Bank as it works to reign in recalcitrant banks.

This notwithstanding, there are elements in the BOFI Act both in wording and substance, that has injected much ambiguity into its interpretation. First, the BOFI Act does not specify who the Board of Directors that must give approval are, leaving us to conjecture whether they are of the licenced bank or the Central Bank. However, we can resolve this uncertainty by reference to Section 6(1) of the Central Bank of Nigeria Act, 2007, which establishes the Board of Directors of the Central Bank and gives it the authority for the policy and general administration of the affairs and business of the Central Bank. With this authorization and in the absence of any other direct provision of the BOFI Act to the contrary, it is safe to presume that the Board of the Central Bank is the one referred to in Section 12(1) of the BOFI Act. Even at that, the ambivalence is not settled yet. This is on account of the possibility of the use of absolute discretion by the governor of the Central Bank when it comes to revocation of the operating licence of banks. There exists a real possibility of a valid interpretation of Section 12(1) of the BOFI Act to the effect that even when a bank has violated the prohibitions, the governor of the Central Bank still has to exercise a discretion to revoke or not notwithstanding any approval of the Board of Directors to revoke. The operating word here is may. Therefore, if the governor decides not to revoke its licence, the erring bank can go on committing malfeasance to the detriment of its customers and the unsuspecting public. This no doubt, would, if not effectively checked, erode the confidence of the banking community and impact negatively on savings. There is yet another question of how the violation can be brought to the attention of the Board of Directors for their approval of revocation. The Act does not provide a clue and so we are allowed another supposition that it is the governor of the Central Bank that draws the attention of the Board to the violation. Following from that, where the governor fails or neglects to do this, then the approval will not be had and the revocation will invariable not take place. This is a major defect in the Act.

There is another instructive provision under Section 17 of the BOFI Act. Section 17(1) bars banks from paying dividends on its shares until all its preliminary expenses, organizational expense, shares selling commission, brokerage, amount of losses incurred and other capitalized expenses not represented by tangible assets have been completely written off; adequate provisions have been made to the satisfaction of the Central Bank for actual and contingent losses on risk assets, liabilities, off balance sheet commitments and such unearned income as are derivable there from; it has complied with any capital ratio requirement under the Act. This, no doubt is an additional fortification for banks against less capitalization and failure. Stability of the banking system is good for the economy in general and for depositors and customers in particular. This notwithstanding, care must be taken to ensure that bank employees and directors do not take opportunity of this to heap unwarranted and unjustifiable expenditures and 
needless commitments on the banks to the end that shareholders are deprived of the just and deserving reward on their investments, for this may retard investments in this sector on the long run. There is a situation in the country where bank staff live in luxury and opulence while millions of their shareholders have little to show for their investment for years on end, and Section 17 of the BOFI Act appears to perpetuate this anomaly.

Aside of its statutory duties under the Act, the BOFI Act allows banks to invest directly in the agricultural and industrial sectors of the economy. By Section 21(1), a bank may acquire or hold part of the share capital of any agricultural, industrial or venture capital company on condition that the venture capital company is set up for the purpose of promoting the development of indigenous technology or the shareholding is in small and medium scale industries and agricultural enterprises. Such investment, however, must not be more than ten percent of the bank's shareholders fund unimpaired by losses and shall not exceed fourty percent of the paid-up share capital of the company. This is good for the economy. By permitting banks to inject needed resources into agriculture, manufacturing and industrialization, and other businesses approved by the Central Bank under Section 21(2), the much needed economic diversification has acquired a definite boost.

The BOFI Act also promotes transparency in the banking system. By Section 18(1), no manager or any other officer of a bank shall in any manner whatsoever whether directly or indirectly have personal interest in any advance loan or credit facility, and where he does must disclose such interest to the bank; or grant any advance, loan or credit facility to any person, unless it is authorized in accordance with the rules and regulations of the bank; or benefit as a result of any advance, loan or credit facility granted by the bank. Section 19(1) forbids employment by the bank of any person who has been adjudged bankrupt, has compounded with his creditors or been convicted by a court of an offence involving fraud, dishonesty, or professional misconduct. Section 19(2) forbids interbank directorship and all bank managers, directors and employees shall endorse a code of conduct and comply with it. Furthermore, Section 27(1) mandates banks to publish not later than four months after the end of each financial year, copies of their balance sheet and profit and loss account signed and containing the full and correct names of the directors of the bank. Copies of these statements of account must also be forwarded to the Central Bank. By Section 28(1), every balance sheet and every profit and loss account of a bank shall give a true and fair view of the state of affairs of the bank at the end of the reporting period. This would definitely make bank operators alive to their duties and obligations under the Act as well as the code of conduct which they are subject to. These provisions of the Act when complied with would create trust and confidence in the banking system and invariably impact positively on the economy. More so, Sections 27(5) and 28(3) impose various penalties for non-compliance and thus makes it unattractive for a bank to risk. 
There is also Section 32(1) where the governor of the Central Bank is given the power to order a special examination or investigation of a bank and its affairs if he is satisfied that it is in the public interest to do so; or the bank has been carrying on its business in a manner detrimental to the interest of its depositors and creditors; or the bank has insufficient assets to cover its liabilities to the public; or the bank has been contravening the provisions of the BOFI Act; or a director, shareholder, depositor or creditor makes an application for such examination. Where the outcome of the examination confirms the situation under Section 32(1), the governor of the Central Bank may take remedial steps under Section 33(2) including prohibiting the bank from extending any further credit facility; requiring the bank to take specific actions or refrain from any acts in relation to the bank or its business; removing any director, manager or officer of the bank from office and appoint any other director or directors; or appoint any person to advise the bank in relation to its business.

Where the health of the bank does not improve in spite of the foregoing, Section 34 of the BOFI Act empowers the Central Bank to turn over the control and management of such bank to the Nigeria Deposit Insurance Corporation to carry on the business of the bank in the name and on behalf of the bank until such a time, in the opinion of the Central Bank, it is no longer necessary for the corporation to remain in control of the business of the bank. ${ }^{8}$ If however, the fortune of the bank cannot be turned around or rehabilitated after all efforts by the Nigerian Deposit Insurance Corporation, the corporation may recommend to the Central Bank other resolution measures including the revocation of the Bank's operating licence. This is, however, a prelude to the liquidation of such bank because section 38 of the BOFI Act stipulates that where the bank's licence is revoked in line with the foregoing, the corporation shall apply to the Federal High Court for a winding up order of the affairs of such bank. ${ }^{9}$ This is certainly a good intervention, particularly on behalf of bank depositors, more so if we recall that under Section 2 of the Nigerian Deposit Insurance Act, which creates the Nigerian Deposit Insurance Corporation, depositors are insured against bank failure and the consequences of a winding-up. This is needful in order to sustain customer confidence in the banking system. This argument is further strengthened by Section 50 of the BOFI Act providing that where a bank is unable to meet its obligations or suspends payments, the assets of the bank anywhere in the country shall be available to the bank or its liquidator to meet all the deposit liabilities of the bank, and such deposit liabilities shall have priority over all other liabilities of the bank. Again, this is necessary for injecting the needed confidence in the banking sector and also good for overall economic growth.

\footnotetext{
${ }^{8}$ Section 35 of the BOFI Act.

${ }^{9}$ Section 38A bars any suit against any bank whose control has been assumed by the Nigerian Deposit Insurance Corporation and if such suits were pending before the takeover of control, they shall abate and cease. By section 38B, the corporation shall while acting as the liquidator of a licenced bank, forward to the Central Bank copies of any returns which it is required to make, from time to time, by the Central Bank.
} 
Section 41(1) of the BOFI Act empowers the Nigerian president to proscribe any trade union of which the members are employed in a bank if he is of the opinion that the activities of the union are calculated to disrupt the economy. Section 41(2) mandates such proscribed union to surrender its certificate of registration to the registrar of trade unions within fourteen days of such proscription. Section 41(3) bars officers of the proscribed union from holding any official position in any trade union of which members are employed by a bank. Section 41(5) punishes any person who holds such a position, on conviction by a court, with a fine of five thousand naira or imprisonment for a term of five years without option of a fine. Refusal to surrender a certificate of registration to the registrar of trade unions after proscription is punishable under Section 41(4) with a fine of five thousand naira or imprisonment for 6 months or to both such fine and imprisonment. The problem with Section 41, however, is that it is not justified under Nigerian law and runs contrary to the basic foundations and principles of that law. The right to freedom of association including the right to join or exit unions or operate them is a constitutional matter secured and guaranteed under Section 40 of the constitution of Nigeria, 1999, which specifically provides that every person shall be entitled to assemble freely and associate with other persons, and in particular he may form or belong to any political party, trade union or any other association for the protection of his interests. The constitution is the grundnorm and stands superior to any other law in the country. ${ }^{10}$ Accordingly, the president cannot wake up simply because he holds an opinion about a union and proceed to proscribe such union. It is not only autocratic but open to abuse by a partisan president. Curiously, the Trade Unions Act ${ }^{11}$ does not give the president such sweeping powers. On the contrary, Section 7(9) of the Trade Unions Act gives power to the Minister of Employment, Labour and Productivity to revoke in the overriding public interest, the certificate of registration of any trade union and such union shall by Section 9(1) (b) stand dissolved within a period of three months in accordance with its rules or constitution. Even though there still exist inherent contentious legal issues under the Trade Unions Act in this regard including that there is no defined ground or event upon which this power may become exercisable, its position is better than what find under the BOFI Act.

Furthermore, Section 52 of the BOFI Act gives the governor of the Central Bank the power to exempt community banks or profit and loss sharing bankls from the provisions of the Act. There is no legal basis or economic justification for this exemption. Though community banks have a federal legislation dealing specifically with their operations, other banks such as the Nigerian Industrial Development Bank, the Nigerian Agricultural and Co-operative Bank, the Nigerian Export Bank, the Nigerian Bank for Commerce and Industry, the Urban Development Bank, the Federal Mortgage Bank of Nigeria and the Peoples Bank

${ }^{10}$ See section 1(1) \& (3) of the Constitution of the Federal Republic of Nigeria, 1999.

${ }^{11}$ The Trade Unions Act, 2005 is a federal legislation that regulates the formation, registration and organization of trade unions, federations of trade unions and the central labour organization. 
of Nigeria also have separate legislations applying specifically to them. ${ }^{12}$ As such, singling out the community banks and potentially exempting them from the application of the BOFI Act is discriminatory and is not based on any sound economic calculation. Section 52, therefore, can only create a loose end in the banking sector. Though Section 32A authorizes the Central Bank to examine from time to time the books and affairs of community banks and other specialized banks, this is grossly inadequate and does not, in the end, make up for the exception under Section 52.

The final defect in the BOFI Act may be located under Sections 53 and 54 of the Act. Section 53 provides that the BOFI Act shall apply without prejudice to the Companies and Allied Matters Act as it relates to banks and to winding up by the Federal High Court. ${ }^{13}$ By ordinary interpretation, this means that the provisions of the BOFI Act shall not obstruct the application of the Companies and Allied Matters Act with regard to the above subject matter. But, not only are the rules laid down by both Acts for winding up of companies and the role of the Federal High Court different, Section 53(2) of the BOFI Act curiously declares that where both Acts conflict, the provisions of the BOFI Act shall prevail. This is quite ambiguous and contradictory in terms. Besides, the declaration is not supported by any legal authority with regard to the hierarchy of legislations in Nigeria. If anything, both the Companies and Allied Matters Act and the Banks and Other Financial Institutions Act are of equal status in the legislative hierarchy and it would not be the position of any one of them to proclaim superiority over the other. Section 54 of the BOFI Act also claims superiority of the Act over the Nigerian Deposit Insurance Corporation Act. ${ }^{14}$ These self contradictory provisions of the BOFI Act creates needless ambiguity and presents difficulty in interpretation whenever the courts get a chance to deal with it.

\section{Conclusion}

The banking sector plays a critical role in the economic development of any nation and is the catalyst for economic growth worldwide. Finance is the life-wire on which resources and its mobilization for economic development revolve (Okpara, 2016). The banking sector is the principal custodian of both public and private finance and also the chief agency through which the government designs its monetary and fiscal policies to attain expected economic objectives. There are a number of legislations that regulate banking in Nigeria, though most of them are restricted only to certain classes of banks. However, the principal legislation that applies to all banks in the country is the Banks and Other Financial Institutions Act. The Act which came into force in 1991 has witnessed several amendments, the last being in 2002, all in a bid to bring it up to date and in tune with current realities and trends of banking and financial deployment for impactful

${ }^{12}$ See the Community Banks of Nigeria Act, 1992; Federal Mortgage Bank of Nigeria Act, 1993; Peoples Bank of Nigeria Act, 1990.

${ }^{13}$ The Companies and Allied Matters Act, 1990, is a federal legislation just like the BOFI Act.

${ }^{14}$ The Nigerian Deposit Insurance Act is a federal legislation. 
contribution to economic growth. Notwithstanding these amendments, the Act is still encumbered by a number of defects and so requires yet another overhaul so as to accomplish its objectives. The paper has examined these defects, particularly as it relates to post-licence additional conditions imposed on banks, too much discretion conferred on the governor of the Central Bank to revoke bank licence, and the unjustifiable exception granted to community banks from the application of the Act, and made recommendations in this regard. Finally, this research provides a working guide for policy makers, bank assessors and examiners, and most importantly to legislators who seek to cure the defects of the BOFI Act and strengthen the Nigerian banking sector for optimal performance.

\section{Recommendations}

It is imperative that certain amendments be effected on the BOFI Act if it must attain its set objectives and make an impactful contribution to economic development in the country. Among them, Section 5(1) of the Act should be amended to remove the uncertainty relating to post-licence additional conditions which the Act gives the Central Bank power to impose on banks on the pain of revocation of their operating licence. Aside of the uncertainty introduced by this requirement on the operation of banks and the sustenance of their licence to operate, there is too much discretionary power generated by this in favour of the governor of the Central Bank. To revoke the licence of any bank even after it has laboured to fulfill the requisite conditions and obtained one is unfair and unjust. Accordingly, banks should not be taken by surprise and impossible conditions imposed on them post-licence. Therefore, once a bank has obtained a licence, it should be allowed to operate subject to the general and uniform rules which the Central Bank can make for smooth banking business and, in particular, to give full effect under Section 55(1) to the objects and objectives of the Act.

Furthermore, Section 12(1) of the BOFI Act should be amended to make it obligatory rather them discretional for the governor of the Central Bank, upon approval of the Board of Directors, to revoke the operating licence of any bank that commits any of the infractions under Section 12. The governor must also be placed under obligation to bring such infraction promptly to the attention of the Board for consideration. This way, excessive discretion on the part of the governor and discriminatory treatment of banks would be avoided. Again, the power conferred by the BOFI Act on the president of Nigeria to proscribe any trade union if he thinks that their activities are disruptive of the economy should be reversed and such powers transferred to the regular courts. This provision, if allowed to continue, may be subject to grave abuses. A president may view workers' agitation for better welfare or their embarkation on strikes as disruptive of the economy and without attending to such legitimate demands unilaterally proscribe their union. This, in the final analysis, would not be in the interest of economic progress. Accordingly, such proscription should only be an outcome of court proceedings. This is more so as Section 41(3) bars an officer of a proscribed 
union from holding any official position in a union constituted of employees of any bank. There is also Section 41(5) that talks about conviction, fine and imprisonment for such officers. These are things that no other authority than a regular court can do without raising fundamental constitutional problems. ${ }^{15}$

Again, Section 52 of the BOFI Act should be amended to remove the exemption granted to potential community banks. Community banks are specialized banks just like a dozen others earlier mentioned. Most specialized banks and regular banks are equally important in economic development and they all deal with a wide range of customers, shareholders, creditors and depositors. Exempting one out of many banks from the BOFI Act is a weak end of the chain in the banking system. Finally, the superiority contest between the Companies and Allied Matters Act, the Nigerian Deposit Insurance Corporation Act and the BOFI Act should be settled once and for all by injecting the BOFI Act into the Nigerian constitution. In that way, its desired superior status under Sections 53 and 54 of the BOFI Act may be accomplished without leaving the current ambiguity and, for that matter, uncertainty to linger.

\section{References}

Adebayo, A. (1999). Economics: A Simplified Approach (2nd ed., Vol. 2). Lagos: African International Publishing Ltd.

Afifia-Oru, B. (2009). Philosophy, Economics and Credit Development. Lagos: BHL Consulting Co. Ltd.

Afolabi, L. (1998) Monetary Economics (Revised Edition). Lagos: Perry Barr Ltd.

Afolabi, L. (1999) Law and Practice of Banking (Revised Edition). Ibadan: Heinemann Educational Books (Nigeria) PLC.

Garner, B. A. (2009). Black's Law Dictionary (9th ed.). St. Paul, MN: West Publishing Co. Okaro, C. S. (2013). Banking Laws and Regulations (2nd ed.). Awka: Abimac Publishers.

Okpara, G. C. (2016). Speculative Financial Bubbles, Volatility and the Nigerian Economy. 22nd Inaugural Lecture of Abia State University, Uturu, Nigeria, 22 June 2016.

Onuoha, J. I. (2013). Development: A Social and Economic Perspective. Owerri: Liu House of Excellence Ventures.

\footnotetext{
${ }^{15}$ For instance, section 36(1) of the constitution of Nigeria, 1999, provides that in determining a person's civil rights and obligations, such a person shall be entitled to a fair hearing within a reasonable time by a court or other tribunal established by law. Similarly, section 36(4) of the constitution states that whenever a person is charged with a criminal offence, he shall be entitled to a fair hearing in public within a reasonable time by a court or tribunal.
} 